\title{
Revision of Physarum pezizoideum var. pezizoideum and var. microsporum (Myxomycetes)
}

\author{
TARJA UKKOLA AND MARJA HÄRKÖNEN
}

UKKOLA, T. \& HÄRKÖNEN, M. 1996: Revision of Physarum pezizoideum var. pezizoideum and var. microsporum (Myxomycetes) - Karstenia 36:41-46. Helsinki. ISSN 0453-3402

\begin{abstract}
The taxonomic status of Physarum pezizoideum (Jungh.) Pavill. \& Lagarde var. pezizoideum and var. microsporum M.L. Farr is re-examined. Checking of the type material of the species showed that var. microsporum is a synonym of var. pezizoideum, while var. pezizoideum sensu Farr belongs to a distinct, new species, described as Badhamia gigantospora Ukkola \& Härk. (type from Tanzania).

Key words: Africa, Badhamia, fungi, Myxomycetes, Tanzania

Tarja Ukkola and Marja Härkönen, Department of Ecology and Systematics, P.O. Box 7, FIN-00014 University of Helsinki, Finland
\end{abstract}

\section{Introduction}

In their study on Tanzanian Myxomycetes, Härkönen and Saarimäki (1991) reported five specimens of Physarum pezizoideum (Jungh.) Pavill. \& Lagarde that were clearly referable to the two varieties described by Farr (1964), viz. var. pezizoideum and var. microsporum M.L. Farr. In Tanzanian material, the differences between the two varieties turned out to be so pronounced that we undertook to study the species more thoroughly, to decide whether the varieties should be recognized as distinct species.

In an examination of 35 collections, identified as Physarum pezizoideum in major myxomycete herbaria, Farr (1964) confirmed the differences in capillitium and spores noted by several workers earlier (e.g. Lister 1925, Hagelstein 1944, Krzemieniewska 1960), and proposed a new variety, $P$. pezizoideum var. microsporum, to accommodate the small-spored specimens. According to her, the variation between var. pezizoideum and var. microsporum was overlapping so that, of the 35 collections examined, seven were intermediate in capillitium and peridium (the basal brown disc) and four were intermediate even in their spore characters. Other specimens were separable into two groups according to the characters of capillitium and spores. Farr (1964, 1976) remarked that the similarity in sporangial form and the intergradation of other characteristics would preclude separation of the two taxa on a species level. As other characters showed some intergradation, she separated the two varieties on the basis of spore size.

Farr (1964) did not examine the type specimen of Physarum pezizoideum; apparently it was deposited in Bogor (BO) and was not available for study. Junghuhn's (1838) original description of Trichamphora pezizoidea does not include spore measurements, and the plate (Junghuhn 1838: pl. 2, fig. 9) does not illustrate a spore. On the basis of the spore description, "sporidia ..... majuscula, nigricantia," Farr (1964) assumed that the type specimen belonged to the largespored taxon.

The spores of Physarum pezizoideum var. microsporum sensu Farr appear dark in mass, they are also rather large for a Physarum. The spores of $P$. pezizoideum var. pezizoideum sensu Farr in turn, are gigantic.

Pavillard and Lagarde (1903) transferred Junghuhn's species from Trichamphora to 
Physarum. According to them, the spores are $10-12 \mu \mathrm{m}$ in diameter and very spiny. Their description was not based on the type specimen, however. Lister's (1925) observation that Junghuhn's type from Java has no lime in the slender threads of the capillitium rather suggests var. microsporum.

We were able to trace Junghuhn's authentic material to Leiden (L), and from there we borrowed two specimens of Trichamphora pezizoidea, both belonging to Junghuhn's collections from Java. There are no signs of typifications on these collections, but we assume that they represent syntypes. Junghuhn's notes accompanying the collections read (translated from latin): "Trichamphora pezizoidea Jungh., new genus. Myxogasteres. 2/12-3/12 inch high. Stipes of sporangia brownish, tapering upwards, gregarious, often in clusters grown together at the basal parts, peridia slightly nodding. Peridium cup-shaped! - Spores large, globose. Capillitia very hair-like, rumpled, tortuous through the spore mass connecting the upper and lower parts of the peridium. Stipes of the sporangia membranous at the base, extended. Djocjo, Java. Collected by Junghuhn. On decayed stem and on hay leaves and straw. Developed after heavy rains. The morning after the sporangia had been removed, one could see new specimens." There is no date on the notes, but the collecting locality, Djocjo, is mentioned. In the article where Junghuhn (1838) describes Trichamphora pezizoidea, he stresses the unique shape of the sporangia: cup-shaped, Peziza-like. $\mathrm{He}$ also remarks about the heavy rains, and writes that the fructifications grew on a decayed log and abundantly on twigs and hay leaves near the log, near Djakarta in April. He also mentions that next day new descendants appeared on the same stem. The description of the species is identical (although more extensive and more detailed) with the remarks on the notes included in the collections lent to us. So without hesitation we labelled one of these specimens as the lectotype of Trichamphora pezizoidea Jungh.

The type specimen is not in good condition. Except in one sporangium, all capillitia have been destroyed and only stipes are left. There are some detached spores on the stipes however. The spores are pale violet brown in transmitted light, minutely spiny, with clusters of more prominent spines, $8-\underline{9.1}-10 \mu \mathrm{m}$ in diameter. The remnants of capillitium in the one sporangium appear as thin, hyaline, branching threads. The detached spores on the capillitium are dark and nearly black under a dissecting microscope. The spores and the capillitial threads are similar to those of the type specimen of Physarum pezizoideum var. microsporum. Junghuhn's description of the capillitium, "very hair-like, rumpled," also refers to this variety. And similarly, Lister"s (1925:72) remark on the slender, noncalcareous capillitial threads of the type specimen refers to $P$. pezizoideum var. microsporum sensu Farr. Rostafi ski (1876) examined a syntype of Trichamphora pezizoidea from Nees von Esenbeck's collections. In his description, the capillitium is composed of thin $(0.8 \mu \mathrm{m})$ threads forming a dense, flexible net. Rostafi ski adds, that Junghuhn's figure of the capillitium (Junghuhn 1838: pl. 2, fig. 9a) is incorrect; the capillitium is not composed of broad, scarcely branching threads forming a loose net as shown in the figure. In Junghuhn's Latin description, and additionally in the notes with the material received from Leiden, the capillitium is not described as coarse and scarcely branching but as delicate and extensively branching.

Because Farr (1964) - apparently incorrectly - assumed that Junghuhn's type specimen belongs to the large-spored group, she proposed a new variety, var. microsporum, to segregate the small-spored collections from the largespored ones. Now, after an examination of the material Junghuhn collected in Java, it seems clear to us that the small-spored variant with delicate, netted capillitium represents the type variant of Physarum pezizoideum. The taxon with large, distinctly spinulose spores and with coarse, column-like capillitial threads filled with lime is actually unnamed.

Junghuhn (1838) described the new species in a new genus, as Trichamphora pezizoidea. Since his time, the species has been transferred to various genera in Physaraceae. According to the widely accepted distinction between the genera Physarum and Badhamia (Martin et al. 1983), based on the construction of the capillitium, the present taxa in fact belong to two different genera. The small-spored taxon belongs to the genus Physarum, but the one with large spores belongs to Badhamia and is here described as Badhamia gigantospora. 


\section{Physarum pezizoideum (Jungh.)} Pavill. \& Lagarde

Trichamphora pezizoidea Jungh., Praem. fl. crypt. Java: 12. 1838. - Chondrioderma pezizoideum ("pezizoides") (Jungh.) Rostaf. luzowce monogr.: 424. 1875. - Didymium pezizoideum (Jungh.) Massee, Monogr. Myxogastr.: 239. 1892. - Type: Indonesia. Java: Djocjo, Junghuhn 163 (L, lectotype, here designated, and isolectotype).

Trichamphora fuckeliana Rostaf., luzowce monogr.: 138. 1874. - Badhamia fuckeliana (Rostaf.) Rostaf., luzowce monogr., Suppl.: 2. 1876. - Type (not seen).

Chondrioderma muelleri Berk. ex Rostaf., luzowce monogr., Suppl.: 15. 1876. - Type (not seen). Physarum pezizoideum var. microsporum M.L. Farr, Brittonia 16: 340. 1964. - Type: Zaire ("Congo") (BPI 71719, holotype).

Sporangia gregarious, stipitate, flat discoid to cupshaped, pure white to greyish white, $1.2-1.5 \mathrm{~mm}$ in diameter, total height $2-4 \mathrm{~mm}$. Peridium membranous, thinly covered with lime granules, breaking irregularly into small patches. Stipe slender, striate, reddish brown, 1.5-2.5 mm long. Hypothallus small, membranous, brownish. Capillitium usually dense, connecting the lower and upper surfaces of the peridium and consisting of branching hyaline tubules connected with some small, mostly fusiform lime nodules. Spores dark brown in mass, pale violet brown in transmitted light, minutely spinulose with clusters of more prominent spines, 8-10 $\mu \mathrm{m}$ in diameter.

\section{Additional material examined}

Romania. Moldavia: Neamt, 1919 Brândza 30(NY). Tanzania. Northern Prov.: Arusha Distr., Arusha National Park, E slope of Mt. Meru, Kitoto campsite (03 36 BD), $2480 \mathrm{~m}$, on a decayed log, 26.V.1988 Härkönen $3435(\mathrm{H})$; Mt. Meru, W slope, NE of Olmotonyi, below Laikinoi, Training Forest of the Sokoine Univ. of Agriculture (03 36 BC), Cupressus lusitanica plantation, $1770-1900 \mathrm{~m}$, on a large fallen trunk (possibly not Cupressus), on mosses, 17.XII.1989 Härkönen 3721 (H); Mt. Meru, SW slope up from Miller Singh sawmill (03 $36 \mathrm{BC}$ ), Olea welwitschii forest, 2100-2200 m, 16.XII.1989 Härkönen $3748(\mathrm{H})$. Tanga Prov.: Lushoto District, West Usambara Mts., Shume-Magamba Forest Reserve N of Lushoto (04 38 CB); slightly thinned dry lower montane forest, 18001850 m, 20.XII.1988 Härkönen \& Saarimäki $3458(\mathrm{H})$.

\section{Badhamia gigantospora Ukkola \& Härk., sp. nov.}

Sporangia gregaria, discoidea vel patelliformia, stipitata, candida, $1.2-1.5 \mathrm{~mm}$ lata, ad altitudinem totam $2.4 \mathrm{~mm}$ alta. Peridium tenue, irregulariter findens. Stipes tenuis, sublatus, striatus, tortus, rubicinosus, 1.5-2.5 mm longus, discum parvum aurantiacum basi peridii formans. Capillitium ut in genere Badhamia, constans ex tubulis columnaribus calce impletis, superficiem superiorem et inferiorem peridii conjungentibus. Massa sporarum picea. Sporae magnae, fuscae luce transmissa in microscopio, valde spinulosae, $19-22-24 \mathrm{~mm}$ in diametro, spinulas usque ad 2 longas includentes.

Type: Tanzania. Northern Prov.: Arusha Distr., Mt. Meru, W slope, NE of Olmotonyi, close to Laikinoi, Training Forest of the Sokoine Univ. of Agriculture (03 36 BC), Cupressus lusitanica plantation, alt. 1900-1950 m. A colony at least $1 / 4-\mathrm{m}^{2}$ wide, on a very large decaying log, 15.XII.1989 Härkönen 3768 (H, holotype; DSM, NENB, isotypes)

Sporangia gregarious, stipitate, discoid to saucer-shaped, pure white, $1.2-1.5 \mathrm{~mm}$ in diameter, total height $2-4 \mathrm{~mm}$. Peridium membranous, thinly covered with lime granules, breaking irregularly into small patches which remain attached to the capillitium. Stipe slender, subulate, striate, twisted, reddish brown, 1.5-2.5 mm long; spreading to a small orange disc on basal portion of peridium. Hypothallus small, brownish, membranous. Capillitium consisting of coarse columns filled with lime and connecting the upper and lower surface of the sporangium. No columella. Spores black in mass, dark brown

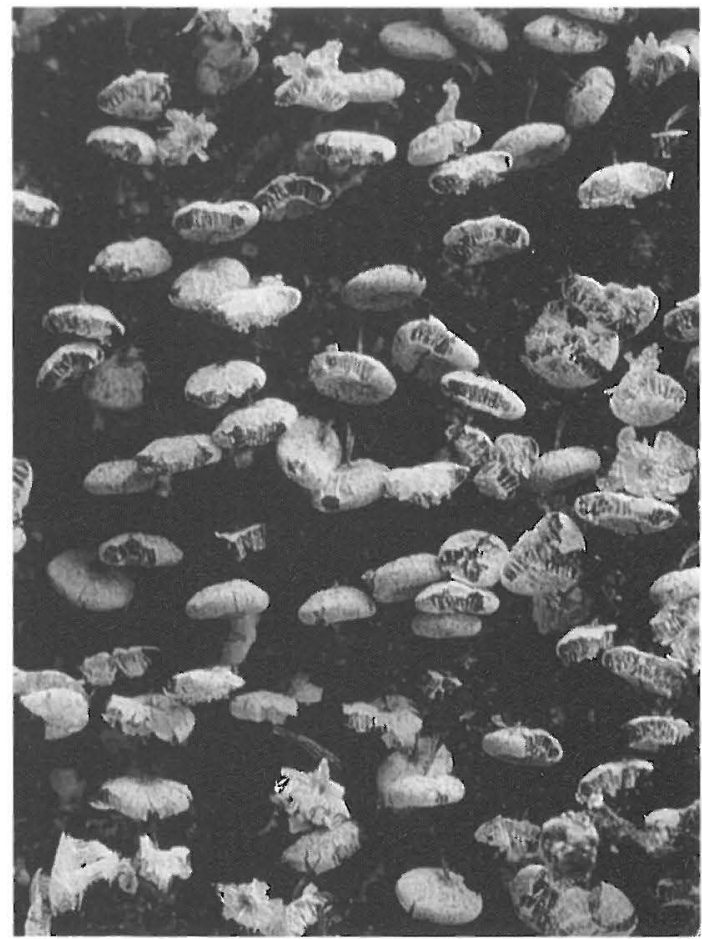

Fig. 1. Badhamia gigantospora (holotype). 

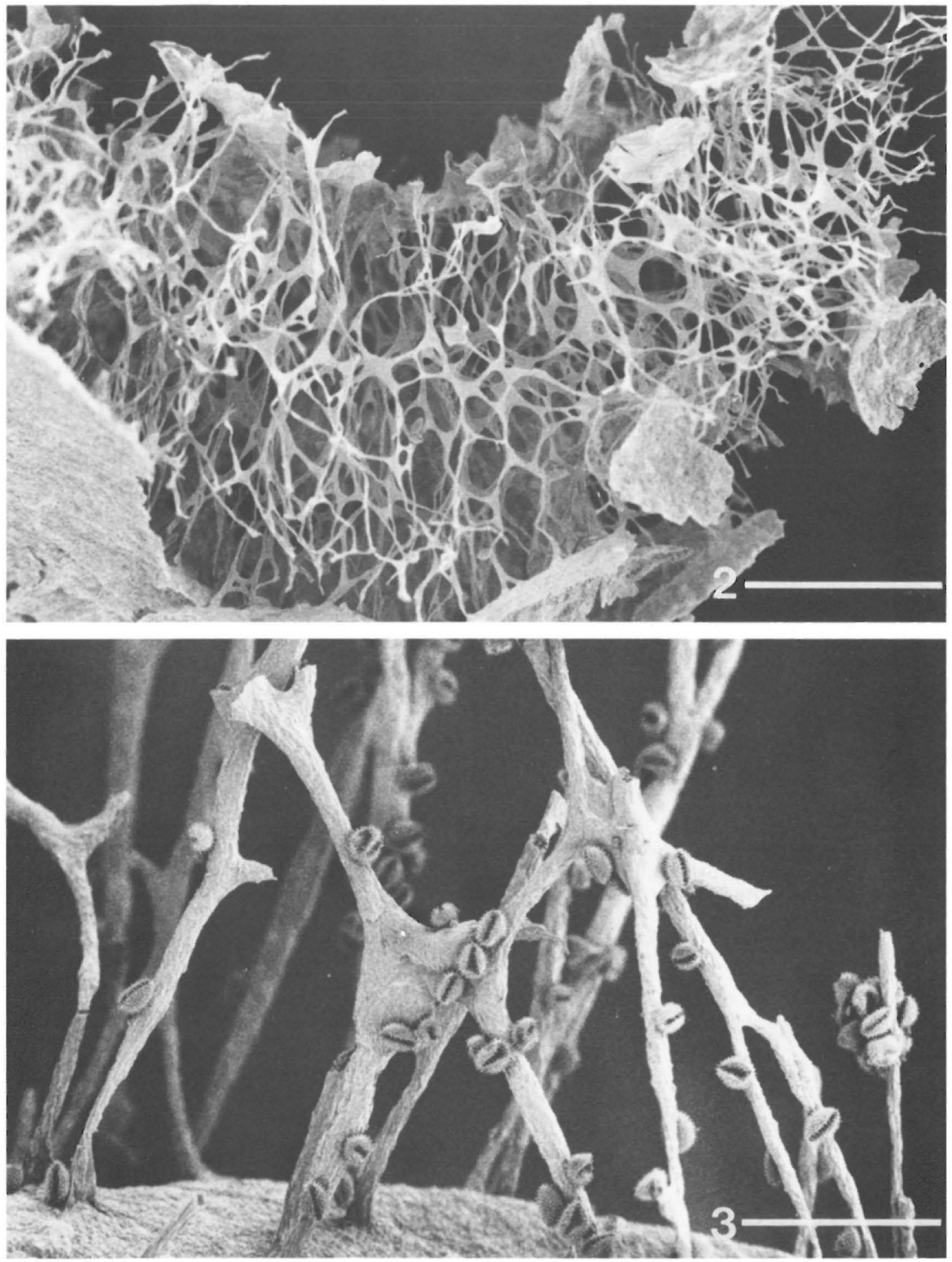

Figs. 2-3. Capillitium and sporangial wall of the two taxa by SEM, in the same magnification, bar $=100 \mathrm{~mm}$. -2 : The dense hair-like capillitium of Physarum pezizoideum (Härkönen 3721). - 3: The coarse capillitial columns of Badhamia gigantospora (holotype). 

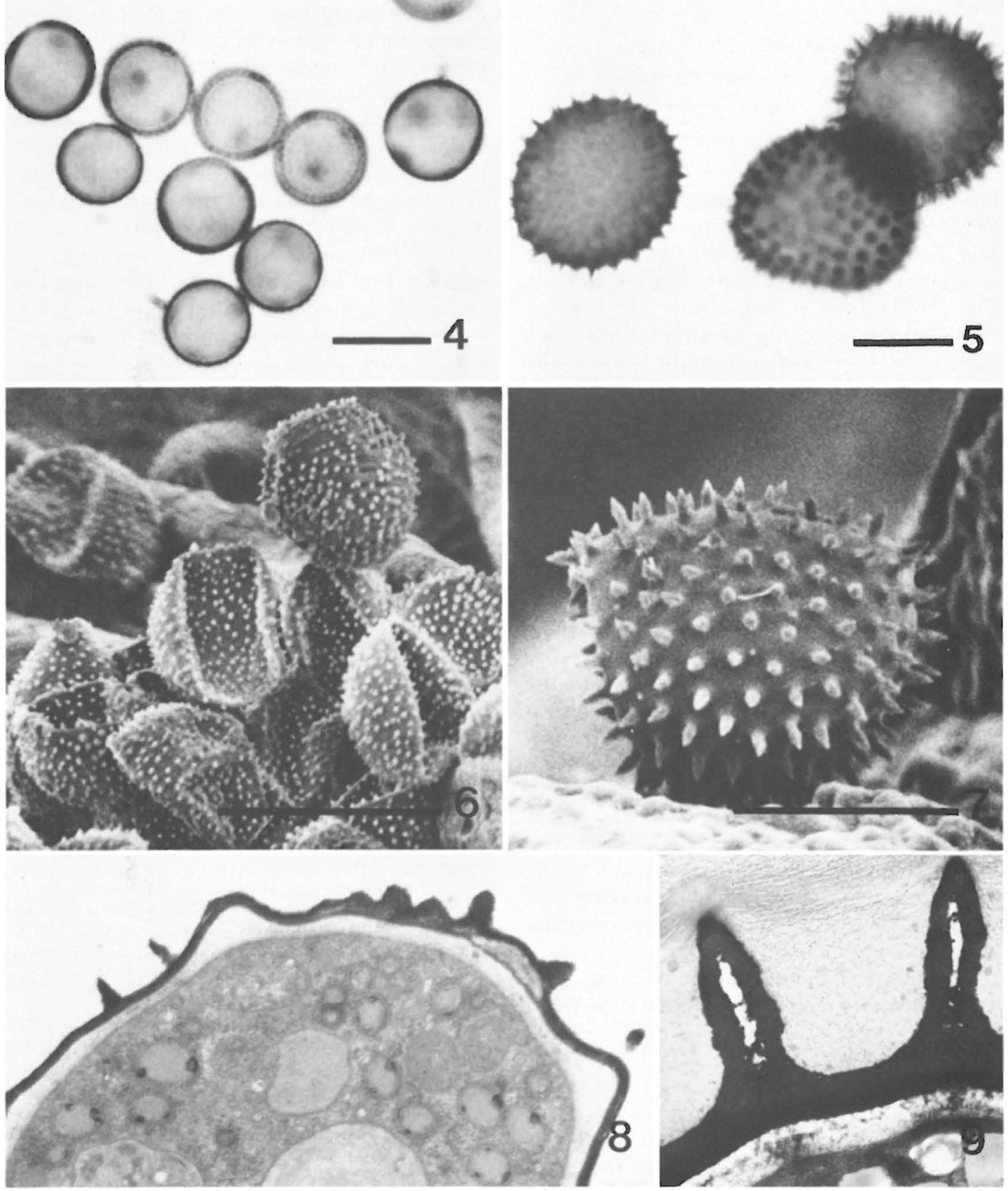

Figs. 4-9. Microscopical details of the spores of the two taxa in the same magnification, bar $=10 \mathrm{~mm}$. $-4-5$ : Compound microscopic photos. 4: Spores of Physarum pezizoideum (Härkönen 3721), ornamented with fine spines. 5: Spores of Badhamia gigantospora (holotype), ornamented with coarse spines. $-6-7$ : SEM micrographs. 6 : Spores of $P$. pezizoideum (Härkönen 3721). 7: A spore of B. gigantospora (holotype). -8-9: TEM micrographs of the spores, $\mathrm{x} 15000$. 8: A spore of $P$. pezizoideum (Härkönen 3721), ornamentation minute spines with clusters of more prominent spines. 9: Hollow, coarse spines of a spore of $B$. gigantospora (holotype). 
by transmitted light, strongly spinulose, 19 22-24 $\mu \mathrm{m}$ including the spines up to $2 \mu \mathrm{m}$ long.

\section{Additional material examined}

Liberia. Banga, 1926 Linder 1259 (NY 9830).

\section{Discussion}

The two species, Physarum pezizoideum and Badhamia gigantospora, look very similar in the field. Both have gregarious, stipitate, pure white to greyish, discoid to cup-shaped sporangia (Fig. 1). Peridium is thin, covered with white lime granules, breaking irregularly into small patches. Stipe is slender, reddish brown. The stipe under the sporangium of Badhamia gigantospora spreads into a small, orange basal disc, lacking in Physarum pezizoideum. Closer examination reveals several differences. Under a dissecting microscope the capillitium of $P$. pezizoideum appears much more delicate than that of $B$. gigantospora. Examination by SEM renders the capillitial differences still more obvious (Figs. 2 and 3 ). The capillitium of $P$. pezizoideum is dense, and the tubules are pale, delicate and branching, forming a net connecting the lower and upper surfaces of the peridium. The threads have broad expansions at the axils and are connected by small, sometimes very scanty, mostly fusiform lime nodes. Occasionally the capillitium is less dense and hair-like, less branching, but never as coarse or column-like as that of $B$. gigantospora. The capillitial tubules of that species are white, coarse, scarcely branching columns filled with lime, connecting the upper and lower surface of the sporangium.

The spores are totally different. In Physarum pezizoideum they are dark in mass, pale violet brown by transmitted light, minutely spiny, with clusters of more prominent spines, 8- $\underline{8.6}-$ $9.5 \mu \mathrm{m}$ in diameter (Figs. $4,6 \& 8$ ). The spores of Badhamia gigantospora are black in mass, dark brown by transmitted light, distinctly spinulose, 19-22-24 $\mu \mathrm{m}$ in diameter, including spines up to $2 \mu \mathrm{m}$ long (Figs. 5, $7 \& 9$ ).

From both the literature and the material examined, it is clear that the spore characters are the most constant ones. In the older literature the spores of Physarum pezizoideum are said to be smooth, but this is probably attributable to only weakly magnifying microscopes. Typically the spores are under $10 \mu \mathrm{m}$ in diameter and minutely spiny, whereas the spores of Badhamia gigantospora may be over $20 \mu \mathrm{m}$ in diameter and coarsely spiny. The capillitium of Physarum pezizoideum is typically physaroid but sometimes almost badhamioid. The capillitium of Badhamia gigantospora seems always to be badhamioid. Some of the species groups in Physaraceae are much more overlapping than these two species; for instance Physarum vernum Somm., P. ovisporum G.Lister and P. cinereum (Batsch) Pers are extensively overlapping. The division between the genera Physarum and Badhamia is similarly gradual, and has led to many transfers of species between the two genera.

Acknowledgements. We wish to thank Prof. Teuvo Ahti for advice on nomenclature. Ms. Vanamo Salo helped with the scanning micrographs. We thank Dr. Elisabeth Gilert (Göteborg) for translating the essential pages of the books by Rostafi ski and Krzeminiewska from Polish to Swedish, and Lic.Phil. Heino Vänskä for the Latin translations. Specimens were kindly lent by the herbaria BPI, L and NY.

\section{References}

Farr, M.L. 1964: Physarum pezizoideum and P. javanicum. - Brittonia 16:339-341.

Farr, M.L. 1976: Myxomycetes. - Flora Neotropica Monogr. 16:1-304.

Hagelstein, R. 1944: The Mycetozoa of North America. - 306 pp. Privately published, Mineola, NY.

Härkönen, M. \& Saarimäki, T. 1991: Tanzanian Myxomycetes: first survey. - Karstenia 31:41-54.

Junghuhn, F.W. 1838: Praemissa in floram cryptogamicam Javae insulae. - 86 pp. Batavia.

Krzemieniewska, H. 1960: luzowce Polski. - 313 pp. Panstwowe Wydawnictwo Naukowe, Warszawa.

Lister, A. 1925: A monograph of the mycetozoa. Ed. 3, revised by G. Lister. - 296 pp., 222 pls. British Mus. (Nat. Hist.), London.

Martin, G.W., Alexopoulos, C.J. \& Farr, M.L. 1983: The genera of Myxomycetes. - 102 pp., 41 pls. Univ. Iowa Press, Iowa City, IA.

Massee, G. 1892: A monograph of the Myxogastres. 367 pp. 12 pls. Methuen \& Co., London.

Pavillard, J. \& Lagarde, J. 1903: Myxomycètes des environs de Montpellier (1). - Bull. Soc. Mycol. France 19:81-105.

Rostafi ski, J. 1874-1876: luzowce (Mycetozoa) monografia. - Pamiet. Towarz. Nauk. Sci. Pary 5(4):1-215 (1874); 6(1):216-432 (1875); Dodatek (Supplement) 8(4): 1-42 (1876).

\section{Received on 11 September 1995}

